Limnol. Oceanogr., 36(7), 1991, 1415-1426

(c) 1991, by the American Society of Limnology and Oceanography, Inc.

\title{
A mathematical model of the manganese cycle in a seasonally anoxic lake
}

\author{
C. A. Johnson, M. Ulrich, L. Sigg, and D. M. Imboden
}

Swiss Federal Institute for Water Resources and Water Pollution Control (EAWAG), Swiss Federal Institute of Technology (ETHZ), CH-8600 Dübendorf

\begin{abstract}
The processes controlling the Mn cycle in a seasonally anoxic lake (Greifensee, Switzerland) were simulated with a dynamic onc-dimensional vertical lake model (CHEMSEE). The chemical parameters compriscd $\mathrm{Mn}(\mathrm{II})$, particulate $\mathrm{Mn}$, and oxygen concentrations and the processes included in the calculations were the $\mathrm{Mn}$ (II) flux from the scdiment, $\mathrm{Mn}$ (II) oxidation, and particulate Mn removal from the water column. Field data from Greifensee obtained in 1988 and 1989 were used to determine the validity of the model and to estimate the rate constant values for the processes. Optimal values of the rate constants were determined by comparison of simulated results with field data and were in general agreement with literature values. The $\mathrm{Mn}$ (II) flux from the sediment exhibited similar seasonal variations in 1988 and 1989. The results show that it is possible to model the Mn cycle in a dynamic system and highlight the necessity of accurately determining the rate laws of the important processes and their relationships to the oxygen content of the waters.
\end{abstract}

The transport of $\mathrm{Mn}$ in lakes and marine systems is greatest at the water-sediment interface where redox gradients are steep. Where oxygen levels in the water column are low, $\mathrm{Mn}$ (II) can be transported by turbulent diffusion from the sediment surface some distance into the water column, creating the typical profiles reported by Davison (1985). The Mn concentration profiles are governed by a number of physical, chemical, and microbiological processes that interact to create a highly dynamic and sensitive system.

The characteristic $\mathrm{Mn}$ profiles found in pore waters are not susceptible to rapid changes and have been modeled with steady state calculations (e.g. Burdige and Gieskes 1983). The determination of reaction rates in the water is made difficult by turbulent diffusion. In oceanographic investigations, steady state may be assumed for some reactions for which changes in mixing rates or diffusion have minor significance within the time scale under consideration. Calculations to date have been limited to diffusion rates and $\mathrm{Mn}(\mathrm{II})$ oxidation rates (e.g.

\footnotetext{
Acknowledgments

We thank Steven Emerson and Bernard Boudreau for review of the manuscript. The work profited from their ideas and suggestions. We also thank Annette Kuhn for providing information on Greifensce sediment trap data and Patrick Hoehener for discussions.
}

Emerson et al. 1979). The modeling of Mn cycling on a macroscopic scale in lakes is more difficult because the smaller dimensions increase boundary influences. Temperature gradients are subject to rapid changes, as are mixing rates and biological activities. Thus, in lakes it is not possible to make calculations with steady state assumptions unless sufficiently short time scales are involved. Instead time-dependent models must be used. For such modeling, lake dimensions and eddy diffusion coefficients must be known. Furthermore, sampling must be sufficiently frequent to resolve rapid changes.

In principle, it is possible to model the Mn cycle in a dynamic lake system. Turbulent mixing rates can be estimated from temperature profiles, and estimates of the processes governing the chemical and $\mathrm{mi}-$ crobial processes are available in the literature. The difficulties lie in obtaining representative depth profiles of the relevant components and in the assumption that processes can be described by a single rate constant as a function of both depth and time. In this study Mn profiles measured in Greifensee, a seasonally anoxic lake, have becn used to show that a simple model can be used to describe Mn cycling in a timevarying system. This approach highlights information that should be determined in order to model Mn cycles in lacustrine systems more accurately. 
Table 1. $\mathrm{Mn}(\mathrm{II})$ fluxes (mmol $\left.\mathrm{m}^{-2} \mathrm{~d}^{-1}\right)$ from sediments.

\begin{tabular}{clll}
\hline Mn(II) flux & & & Site \\
\hline $0.23 \pm 0.07$ & Pore-water gradient & Lake Zürich & Beference \\
$0.26 \pm 0.09$ & Pore-water gradient & Lake Geneva & Brandl 1987 \\
0.37 & Flux chamber & Lake Washington & Murray 1987 \\
0.19 & Pore-water gradient & Lake Washington & Murray 1987 \\
0.11 & Mass balance & Lake Washington & Murray 1987 \\
$0.05-0.41$ & Flux chamber & Narrangansett Bay & Hunt 1983 \\
$1.2-2.3$ & Concn gradient above sediment & Rostherne Mere & Davison and Woof 1984 \\
0.09 & Pore-water gradient & Gullmars Fjord & Sundby et al. 1986 \\
$(0.07)$ & Flux chamber & Gullmars Fjord & Sundby et al. 1986 \\
\hline
\end{tabular}

Processes involved in the $\mathrm{Mn}$ cycle

$M n$ oxide reduction - It has been well established that the reduction of Mn oxides can be microbially mediated. Investigations of $\mathrm{Mn}$ oxide reduction have been undertaken in both laboratory and field studies. Laboratory studies have shown that microorganisms are capable of reducing $\mathrm{Mn}$ oxides via enzymatic mechanisrns or through their metabolic end products, including sulfide, but the evidence for heterotrophic microbes that use Mn oxides as electron sinks in their metabolism is scanty (Ehrlich 1987). The reduction of $\mathrm{Mn}$ oxides by sulfide and $\mathrm{Fe}(\mathrm{II})$, irrespective of origin, is rapid and organic compounds are also able to act as reductants (Stone and Morgan 1987). Investigations have shown that certain microbial species can reduce $\mathrm{Mn}$ oxides aerobically (Ghiorse 1985).

Field studies have focused on Mn oxide rcduction in scdiments. Because sediments can be major sources of $\mathrm{Mn}$ (II) in eutrophic lacustrine and estuarine systems, much attention has been paid to determining $\mathrm{Mn}$ (II) fluxes into the water. Fluxes have been determined by calculating the increase in the mass of $\mathrm{Mn}$ (II) per unit of surface area as a function of time, by interpreting vertical $\mathrm{Mn}$ (II) profiles in the top layers of the sediment, or by measuring in situ with flux chambers. Murray (1987) used these different methods in a comparative study and found that their results varied by a factor of only 2 (Table 1 ). The flux measurements reported in Table 1 are in the range 0.07$2.3 \mathrm{mmol} \mathrm{m}^{-2} \mathrm{~d}^{-1}$, in reasonable agreement considering the variety of field environments and the differences in methodology.

$\mathrm{Mn}(\mathrm{II})$ oxidation-Mr(II) oxidation in natural waters occurs homogeneously, in heterogenous systems where surfaces act as catalysts, or through microbial mediation. $\mathrm{Mn}$ (II) oxidation by oxygen in homogeneous solution is extremely slow. Morgan and coworkers (e.g. Davies and Morgan 1989) have investigated abiotic oxidation of $\mathrm{Mn}$ (II) and determined the following rate equation:

$$
\begin{aligned}
\frac{-\mathrm{d}\left[\mathrm{Mn}^{2+}\right]}{\mathrm{d} t}= & {\left[\mathrm{Mn}^{2+}\right] \cdot[\mathrm{OH}]^{2} \cdot\left[\mathrm{O}_{2}\right] } \\
& \cdot\left(k_{1}+k_{2} \cdot[\text { solid }]\right) .
\end{aligned}
$$

Here $k_{1}$ and $k_{2}$ are the homogeneous and heterogeneous rate constants, having values of $\sim 4 \times 10^{12} \mathrm{M}^{-3} \mathrm{~d}^{-1}$ and $1-5 \times 10^{18} \mathrm{M}^{-4}$ $\mathrm{d}^{-1}\left(25^{\circ} \mathrm{C}\right)$. Oxidation in Greifensee waters occurs most often where $\mathrm{O}_{2}$ has a concentration of $\sim 3 \times 10^{-5} \mathrm{M}$ and $\mathrm{pH}$ is $7.6\left(K_{n}\right.$ $=14.73$ at $5^{\circ} \mathrm{C}$ ). Assuming a solids concentration of $10^{-5} \mathrm{M}$, we obtain pseudo-firstorder rate constants of $7 \times 10^{-7} \mathrm{~d}^{-1}$ and 2$9 \times 10^{-6} \mathrm{~d}^{-1}\left(5^{\circ} \mathrm{C}\right)$.

Reported values of microbial oxidation are many orders of magnitude faster (Table 2). The rate equations are assumed to be first-order with respect to $\mathrm{Mn}(\mathrm{II})$. Tebo and Emerson (1985) observed a significant increase of the microbial oxidation rate (2-3 times faster) when they increased the proportion of air in the air $/ \mathrm{CO}_{2} / \mathrm{N}_{2}$ mixture from 5 to $100 \%$.

Emerson (1980) determined Mn(II) oxidation rates in the waters of Saanich Inlet with simple mass balance calculations and assumed steady state conditions. He determined rate constants of $0.15-0.62 \mathrm{~d}^{-1}$, which compare favorably to those describing microbial oxidation (0.04-0.74 $\left.\mathrm{d}^{-1}\right)$. De Vitre 
Table 2. Microbial pseudo-first-order oxidation rates of $\mathrm{Mn}(\mathrm{II})$ in natural waters.

\begin{tabular}{ccll}
\hline \hline$k_{\mathrm{ox}}\left(\mathrm{d}^{-1}\right)$ & $T\left({ }^{\circ} \mathrm{C}\right)$ & \multicolumn{1}{c}{ Site } & \multicolumn{1}{c}{ Reference } \\
\hline 0.04 & 21 & Tamar estuary, freshwater & Vojak et al. 1985 \\
0.28 & - & Oneida Lake & Chapnick et al. 1982 \\
0.74 & 7.5 & Rhone River & Balikungeri et al. 1985 \\
$0.19^{*}$ & 20 & Lac de Bret & De Vitre 1986 \\
$0.01-0.39 \dagger$ & 9 & Saanich Inlet & Tebo and Emerson 1985 \\
\hline
\end{tabular}

* Average of 10 experiments.

† 95-115-m depth.

(1986) showed that differing oxidation rates are obtained depending on experimental conditions (e.g. stirring rate, vessel material) and on the sample site. He took samples from various depths in a eutrophic lake. Faster oxidation rates were obtained for anoxic samples containing Mn(II). These results reflect the differences in bacterial populations in the water column.

Particulate $\mathrm{Mn}$ settling-Mn oxide particles in natural waters have various morphotypes, including filamentous morphology (Tipping et al. 1985) and spherical particles (e.g. De Vitre 1986), as they are often oxidation products surrounding bacteria. Settling characteristics depend strongly on morphology and it is difficult to predict exact sedimentation rates. The settling of such particles is most accurately described by coagulation processes (Weilenmann et al. 1989).

$\mathrm{MnCO}_{3}$ precipitation-Solubility of $\mathrm{Mn}(\mathrm{II})$ is limited by precipitation of $\mathrm{MnCO}_{3}$. The solubility product of $\mathrm{MnCO}_{3}$ has a value of $\log K_{\mathrm{so}}=-10.44$ (Stumm and Morgan 1981). The average $\mathrm{pH}$ of the deep hypolimnion is 7.5 and the alkalinity is $\sim 4 \mathrm{mM}$. The maximal concentration of $\mathrm{Mn}$ (II) in equilibrium with $\mathrm{MnCO}_{3}$ is thus calculated to be $10 \mu \mathrm{M}\left(5^{\circ} \mathrm{C}\right)$. Because, with only two exceptions, all measured $\mathrm{Mn}$ (II) concentrations were well below this level, we did not include this process in our calculations.

$\mathrm{Mn}(\mathrm{II})$ sorption on colloidal particlesTrace-metal sorption to colloidal particles can be important in regulating their content and transport in natural water systems. The extent of sorption is dependent on solution chemistry, the nature of the particles, and the relative concentrations of sorbent and sorbate. An assessment of the importance of $\mathrm{Mn}$ (II) sorption to particulate material has been carried out on the basis of the sorp- tion studies of Müller and Sigg (1990). The sorption capacity of particles taken from the small river emanating from Greifensee was $\sim 0.01 \mathrm{~mol} \mathrm{~kg}^{-1}$. In terms of the particulate material in the lake, this value corresponds to $\sim 2 \times 10^{-8} \mathrm{M}$. Because the concentrations of $\mathrm{Mn}(\mathrm{II})$ are in the micromolar range, sorption does not play an important role in the regulation of the $\mathrm{Mn}$ (II) content of Greifensee waters.

\section{CHEMSEE}

The calculations have been carried out with CHEMSEE on an Apple Macintosh PC. It is a user-friendly and flexible simulation tool for modeling chemical, biological, and physical processes in lakes (Ulrich 1989). Models are built interactively by the uscr who can define lake parameters and introduce model variables and processes with menu commands. On the basis of the definitions, the program automatically creates the differential equations. During a simulation run the program calculates the numerical solution of the equations and displays the results graphically. Numerical values and the model definitions can be stored on files.

The lake is described with a one-dimensional vertical model (Imboden and Schwarzenbach 1985). Vertical transport is described by a depth- and time-dependent eddy diffusion coefficient. Vertical advection may also occur due to the compensatory flow caused by subsurface water inputs or rivers plunging below the lake surface. The lake area decreases with depth, so fluxes at the water-sediment interface may occur in each box. Horizontal gradients are neglected, i.e. horizontal mixing is assumed to be fast compared to reaction and fluxes at the lateral sediment boundaries.

The continuous differential equations 


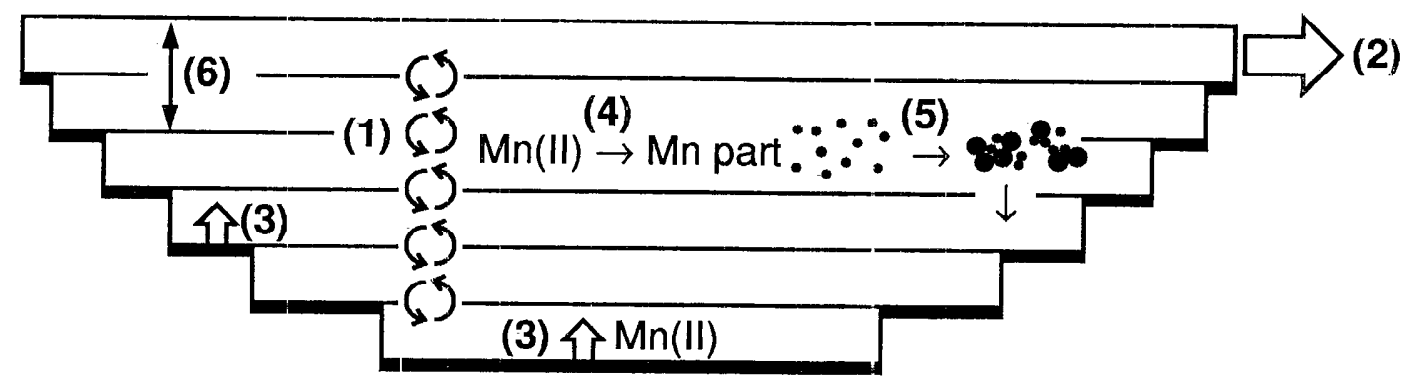

Fig. 1. One-dimensional vertical lake model of the Mn cycle. The figure shows the separation of the lake into horizontal boxes, and the processes and variables of the Mn cycle (numbers refer to processes, explained in the text and Table 4). The variable sediment area per box, reflecting lake topography, is highlighted by black: bars at the box bottoms.

must be spatially resolved to be solved numerically. In CHEMSEE the method of finite volumes is used. The continuous depth coordinate is replaced by a set of adjacent boxes (Fig. 1). The continuous model variables $c_{i}=c_{i}(z)$ are replaced by discrete variables $c_{i, j}$ (concentration of variable $i$ at center of box $j$ ). Spatial derivatives are replaced by finite differences: in the term describing eddy diffusion, $\partial^{2} / \partial z^{2}$ is replaced by centered differences; for the advective flow, upstream differencing, which is numerically very stable (Noye 1984), was used.

The integration algorithm used is a firstorder, explicit Euler method with variable step size. The integration step is adjusted in a user-defined range in such a way that the maximal relative change of the model variables does not exceed a given value. This algorithm is quite stable and well suited for the type of models calculated with CHEMSEE.

\section{Calibration of the physical parameters}

The lake is characterized by a set of geometric and hydraulic data (Table 3). The topography of the lake basin is included in the model by the lake cross section at various depths (Fig. 1); this parameter is used to calculate the volume of the boxes and the area of sediment in contact with each box. The latter is important for all transport processes across the water-sediment interface.

Coefficients of vertical eddy diffusion (No. 1 in Fig. 1) were calculated from temperature profiles for 1988 and 1989 by means of the temperature method (Imboden et al. 1979). This method can be used under the assumption that all heat is transported to deeper layers of the lake by vertical eddy diffusion (no advective heat transport, no significant geothermal heat flow). Intensive water mixing in surface layers creates of wellmixed zone. This zone is called the "epilimnion" (No. 6). It is considered as one box in the model; its depth is determined from temperature and oxygen profiles. Neglecting horizontal mixing is justified for many cases, such as substances entering the lake at boundaries (water surface, sediments) or compounds that react more slowly when they are mixed horizontally.

As shown by Imboden and Joller (1984) for the case of ${ }^{222} \mathrm{Rn}$, whose half-life of 3.8 $\mathrm{d}$ is of the same order as the reaction time of $\mathrm{Mn}(\mathrm{II})$, vertical profiles of compounds taken at the deepest point of the lake can still be interpreted in terms of a one-dimensional model with depth-dependent lake cross section (the CHEMSEE approach), although the apparent vertical eddy diffusion coefficient may be different from the "real" vertical eddy diffusivity. Caution is warranted if the models are applied to profiles taken at the sides of the lake basin. Nearbottom values of measured concentrations may then be significantly different from the profiles calculated by the model. The data used in this study all refer to the midlake station.

\section{Construction of the Mn model and general procedure}

For the purpose of calculations, the $\mathrm{Mn}$ cycle is regarded as consisting of two species: in reduced form as $\mathrm{Mn}$ (II) and in ox- 
idized form as Mn(III, IV) oxide (referred to as particulate $\mathrm{Mn}$ or $\mathrm{Mn}_{\mathrm{p}}$ ). These species are the dynamic variables of the model. The third variable is oxygen. Oxygen is a static variable for which the filed data are used because oxygen concentrations are not significantly influenced by the Mn cycle. Oxygen plays a critical role in the Mn cycle. Above a critical oxygen level, $\mathrm{Mn}$ (II) does not diffuse from the sediments; below a critical oxygen concentration, $\mathrm{Mn}$ (II) is not oxidized to Mn oxide.

$\mathrm{Mn}$ (II) is derived from reduction of $\mathrm{Mn}$ oxides in the sediment and the water. The flux of reduced $\mathrm{Mn}$ from the sediment is the most important source of $\mathrm{Mn}(\mathrm{II})$ in Greifensee. The flux of Mn(II) from the sediment is treated as a zero-order reaction (Table 1) and the rate constant has units of mmol m $\mathrm{m}^{-2} \mathrm{~d}^{-1}$. In the absence of better information, oxygen threshold concentrations were adopted.

Mn(II) can be removed from the water by oxidation, adsorption on colloidal material, and precipitation as $\mathrm{MnCO}_{3}$. The latter two processes have been omitted because they have only a limited effect on the model calculations. The oxidation reaction, however, is an important sink of $\mathrm{Mn}$ (II). In our calculations we have compared two oxidation rate laws. The first (model $\mathrm{A}$ ) is a pseudo-first-order reaction with respect to $\mathrm{Mn}(\mathrm{II})$, in accordance with the microbial oxidation reaction rates shown in Table 2 assuming an oxygen concentration threshold value. The second (model B) assumes a second-order rate equation with the oxygen concentration included in a Michaelis-Menten relationship. The oxygen threshold value is implicit in the Michaelis-Menten equation (Table 4).

The Mn cycle is completed by coagulation and subsequent sinking of the freshly formed particles of $\mathrm{Mn}$ oxide to the lake bottom. In this model coagulation has been assumed to occur at a uniform rate throughout the water column and for the whole data set and has been represented by a pseudo-first-order reaction with respect to the Mn oxide concentration. It has also been assumed that the aggregated particles settle at a uniform velocity. The rate-limiting step of this process is the coagulation of Mn particles. Thus
Table 3. Physical parameters of Greifensee.

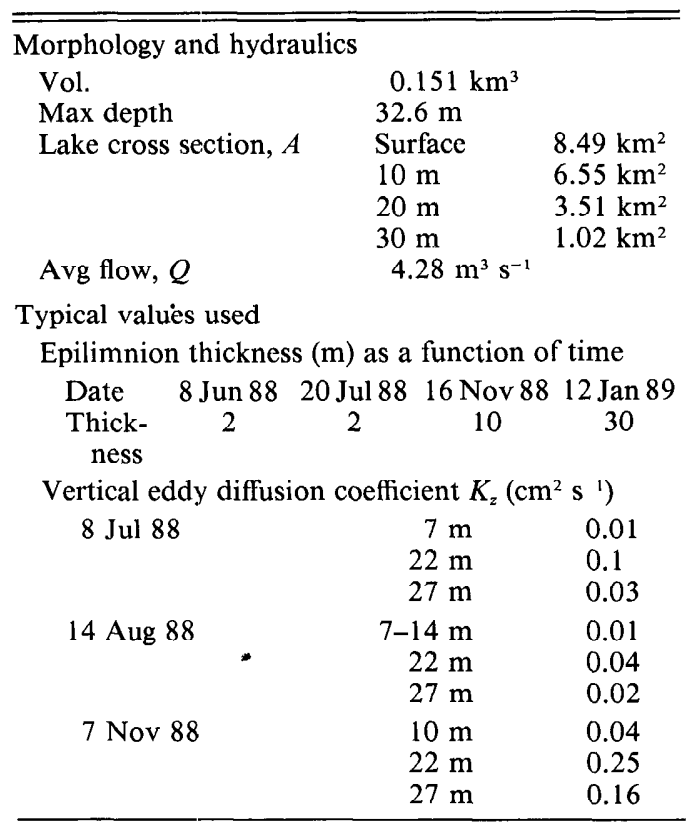

the coagulation rate is the major parameter, whereas particle settling is too fast to play a determining role. Such assumptions oversimplify the actual processes but have been adopted because the data do not justify more detailed analysis.

Reduction of Mn oxides in the water plays only a minor role in Greifensee, in contrast to other systems where inorganic reductants $\mathrm{S}(-\mathrm{II})$ and $\mathrm{Fe}(\mathrm{II})$ are most probably responsible for reduction of $\mathrm{Mn}$ oxide to $\mathrm{Mn}$ (II) in the water (e.g. De Vitre 1986). Inorganic reductants are found only in the bottom 3 $\mathrm{m}$ of the lake $\sim 1$ month before turnover. A comparison of the sedimentation rate of coagulated $\mathrm{Mn}$ oxide determined from model calculations with sediment trap data, both of which were of the same order of magnitude $\left(\sim 10-50 \mathrm{mg} \mathrm{m}^{-2} \mathrm{~d}^{-1}\right)$, showed that the reduction process could be omitted from calculations.

Field data used in the model calculations were taken from an investigation of the lake carried out in 1988 and 1989. Sampling techniques and the processes controlling the chemical composition of Greifensee waters are fully discussed by Sigg et al. (1991). The model (equations in Table 4) was used to 
Table 4. Equations for the one-dimensional vertical lake model describing the Mn cycle. Numbers in parentheses refer to the processes (see Fig. I).

Model equations

$\mathrm{Mn}(\mathrm{II})$ concentration:

$$
\frac{\partial c_{1}}{\partial t}=\frac{K_{z}}{A} \frac{\partial}{\partial z}\left(A \frac{\partial c_{1}}{\partial z}\right)-q^{*} c_{1}+\frac{F^{*}}{A} \frac{\mathrm{d} A}{\mathrm{~d} z}-k_{\mathrm{ox}}{ }^{*} c_{1}
$$

Particulate Mn oxide concentration:

$$
\frac{\partial c_{2}}{\partial t}=\frac{K_{z}}{A} \frac{\partial}{\partial z}\left(A \frac{\partial c_{2}}{\partial z}\right)-q^{*} c_{2}+k_{\mathrm{o} \times}^{*} c_{1}-k_{\mathrm{co}} c_{2}
$$

Variables and parameters

$c_{1} \quad$ Concentration of dissolved $\mathrm{Mn}(\mathrm{II}), \mu \mathrm{M}$

$c_{2} \quad$ Concentration of particulate $\mathrm{Mn}$ oxide, $\mu \mathrm{M}$

$K_{z} \quad$ Vertical eddy diffusion coefficient, $\mathrm{cm}^{2} \mathrm{~s}^{-1}$

A Lake cross section, $\mathrm{m}$

$z \quad$ Lake depth, $\mathrm{m}$

$q^{*} \quad$ Hydraulic rate, $\mathrm{d}^{-1}$

$q^{*}=\left\{\begin{array}{l}Q / V_{1} \text { in top box (discrete formulation) } \\ 0 \text { in }\end{array}\right.$

$\begin{cases}0 & \text { in other boxes (discrete formulation) }\end{cases}$

$Q \quad$ Water flow through lake, $\mathrm{m}^{3} \mathrm{~d}^{-1}$

$V_{1} \quad$ Volume of box 1 (top box, discrete formulation), $\mathrm{m}^{3}$

$F^{*} \quad$ Sediment flux of $\mathrm{Mn}(\mathrm{lI}), \mathrm{mmol} \mathrm{m}^{-2} \mathrm{~d}^{-1}$, $F^{*}= \begin{cases}F & {\left[\mathrm{O}_{2}\right] \leq\left[\mathrm{O}_{2}\right]_{\mathrm{f}}} \\ 0 & {\left[\mathrm{O}_{2}\right]>\left[\mathrm{O}_{2}\right]_{\mathrm{f}}}\end{cases}$

$\left[\mathrm{O}_{2}\right]$ Oxygen concentration, $\mathrm{M}$ (field data)

$\left[\mathrm{O}_{2}\right]_{\mathrm{f}}$ Threshold oxygen concentration for sediment flux, $M$

$k_{t) x}^{*} \quad$ Oxidation rate of $\mathrm{Mn}(\mathrm{II})$ to $\mathrm{Mn}$ oxide, $\mathrm{d}^{-1}$

Model A-pseudo-first-order reaction with an oxygen threshold value:

$k_{\mathrm{ox}}^{*}= \begin{cases}k_{\mathrm{ox}} & {\left[\mathrm{O}_{2}\right] \geq\left[\mathrm{O}_{2}\right]_{\mathrm{ox}}} \\ 0 & {\left[\mathrm{O}_{2}\right]<\left[\mathrm{O}_{2}\right]_{\mathrm{ox}}}\end{cases}$

Model $\mathrm{B}-$ second-order reaction with $\mathrm{Mi}$ chaelis-Menten saturation for oxygen:

$\left.k_{\mathrm{ox}}{ }^{*}=k_{\mathrm{ox}}\left\{\left[\mathrm{O}_{2}\right] /\left[\mathrm{O}_{2}\right]+\left[\mathrm{O}_{2}\right]_{\mathrm{min}}\right)\right\}$

$\left[\mathrm{O}_{2}\right]_{\mathrm{ox}}$ Threshold oxygen concentration for oxidation of $\mathrm{Mn}(\mathrm{II}), \mathrm{M}$

$\left[\mathrm{O}_{2}\right]_{\mathrm{m}} \quad$ Michaelis constant for oxygen, $\mathrm{M}$

$k_{\text {co }}$ Coagulation rate of particulate $\mathrm{Mn}$ oxide, $\mathrm{d}^{1}$

Processes of the model

(1) Eddy diffusion for $\mathrm{Mn}(\mathrm{II})$ and $\mathrm{Mn}_{\mathrm{p}}$

(2) Outflow of $\mathrm{Mn}(\mathrm{II})$ and $M n_{p}$ from the lake

(3) Flux of $\mathrm{Mn}$ (II) from the sediment

(4) Oxidation of $\mathrm{Mn}(\mathrm{II})$ in the water column

(5) Coagulation and subsequent rapid sedimentation of $\mathrm{Mn}_{\mathrm{p}}$

(6) Mixing of the epilimnion (not included in continuous equations)
Table 5. Best-fit parameter values used for the model

\begin{tabular}{|c|c|c|}
\hline & Date & $F\left(\mathrm{mmol} \mathrm{m}^{-2} \mathrm{~d}^{-1}\right)$ \\
\hline $\begin{array}{l}\text { Sediment flux of } \\
\quad \operatorname{Mn}(\mathrm{II}), F\end{array}$ & $\begin{array}{l}8 \text { Jun } 88 \\
8 \text { Jul } 88 \\
27 \text { Jul } 88 \\
12 \text { Jan } 89\end{array}$ & $\begin{array}{l}1.0 \\
1.0 \\
0.2 \\
0.0\end{array}$ \\
\hline \multicolumn{2}{|c|}{$\begin{array}{l}\text { Threshold oxygen concentration } \\
\text { sediment flux, }\left[\mathrm{O}_{2}\right]_{\mathrm{f}} \\
\text { Oxidation rate of } \mathrm{Mn}(\mathrm{II}) \text { to } \mathrm{Mn} \\
\text { oxide, } k_{\mathrm{ox}}\end{array}$} & $\begin{array}{l}5 \times 10^{-5} \mathrm{M} \\
0.2 \mathrm{~d}^{-1}\end{array}$ \\
\hline \multicolumn{2}{|c|}{$\begin{array}{l}\text { Mn(II) oxidation, }\left[\mathrm{O}_{2}\right]_{\mathrm{ox}} \\
\text { Michaelis constant for oxygen }\end{array}$} & $3 \times 10^{-5} \mathrm{M}$ \\
\hline \multicolumn{2}{|c|}{$\left[\mathrm{O}_{2}\right]_{\mathrm{m}}$} & $3 \times 10^{-5} \mathrm{M}$ \\
\hline Mn oxide, $k_{\text {co }}$ & & $0.035 \mathrm{~d}^{-1}$ \\
\hline
\end{tabular}
of the Mn cycle.

simulate depth profiles of $\mathrm{Mn}$ (II) and $\mathrm{Mn}_{\mathrm{p}}$, and the best values for the rate constants and oxygen threshold concentrations were estimated (Table 5). First estimates were obtained from the 1988 data set by calculations from one sampling period to the next, but finally the results were incorporated into one model for the whole year. The estimated constants were applied to the 1989 data set. Single values of rate constants werc used because the quantity of field data avail-. able did not justify depth and time resolution of these constants. Only the change in $\mathrm{Mn}$ (II) flux from the sediment exhibited a time-dependent change strong enough to al-low investigation.

\section{Results and discussion}

Field data (1988) - The influence of oxygen concentration on the Mn cycle is clearly discernible (Fig. 2). In June 1988, the oxygen concentrations start to decline in bottom waters as a result of stratification, preventing replenishment of consumed oxygen. Concurrently $\mathrm{Mn}$ (II) appears at depths $>28 \mathrm{~m}$, and a peak of $\mathrm{Mn}_{\mathrm{p}}$ is found at the intersection of oxygen and Mn(II). These features become more pronounced through June and July as Mn(II) diffuses rapidly out of the sediment. At the end of August oxygen concentrations below $10 \mathrm{~m}$ are not measurable $\left(<6 \times 10^{-6} \mathrm{M}\right)$, and $\mathrm{Mn}$ (II) starts to diffuse out from the lateral sediments below this depth. $\mathrm{Mn}_{\mathfrak{n}}$ is very low at 


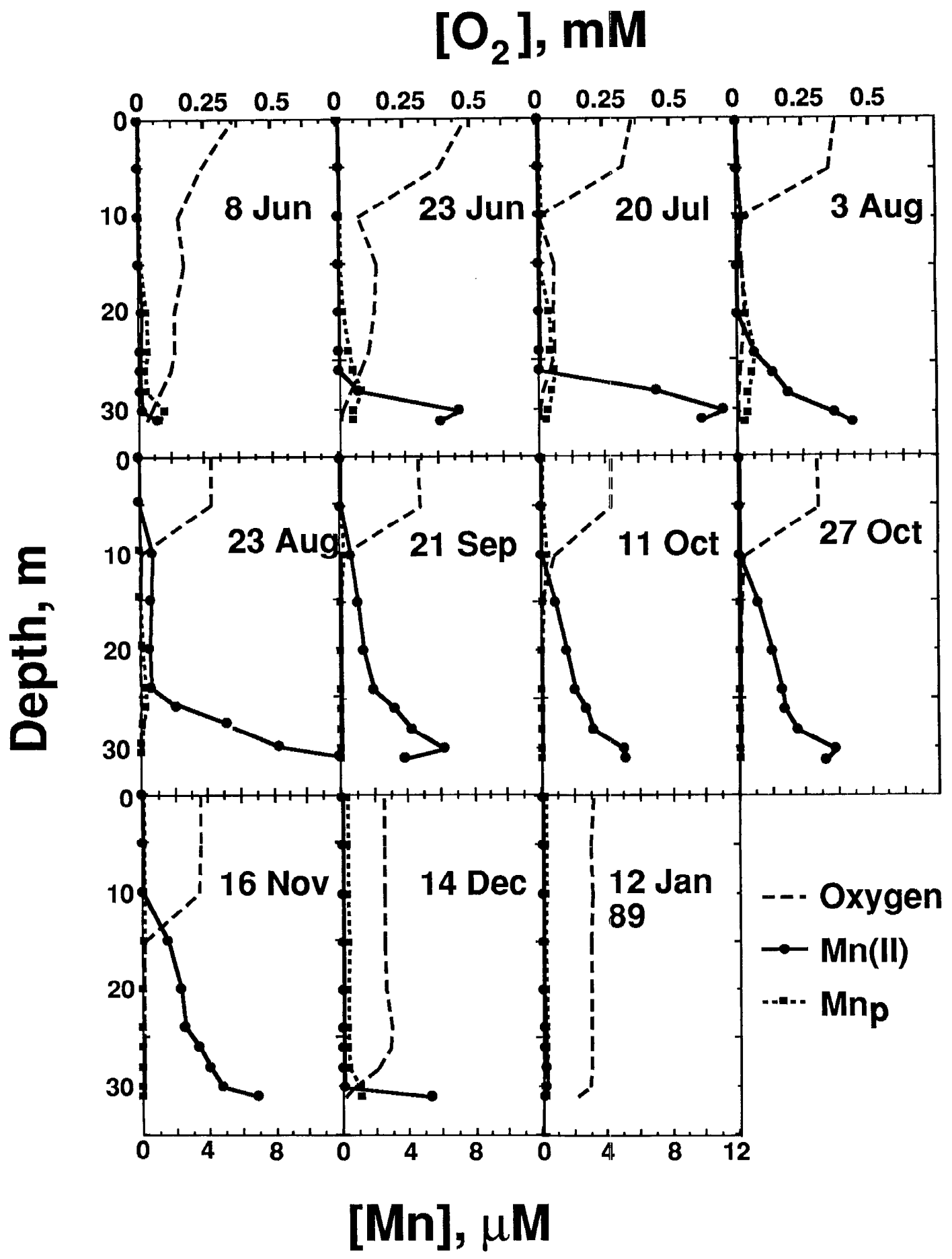

Fig. 2. Depth profiles of $\mathrm{Mn}(\mathrm{II}), \mathrm{Mn}_{\mathrm{p}}$, and oxygen in Greifensee in 1988. These data provide the basis of model calculations. Oxygen content was measured at 1-m intervals. 


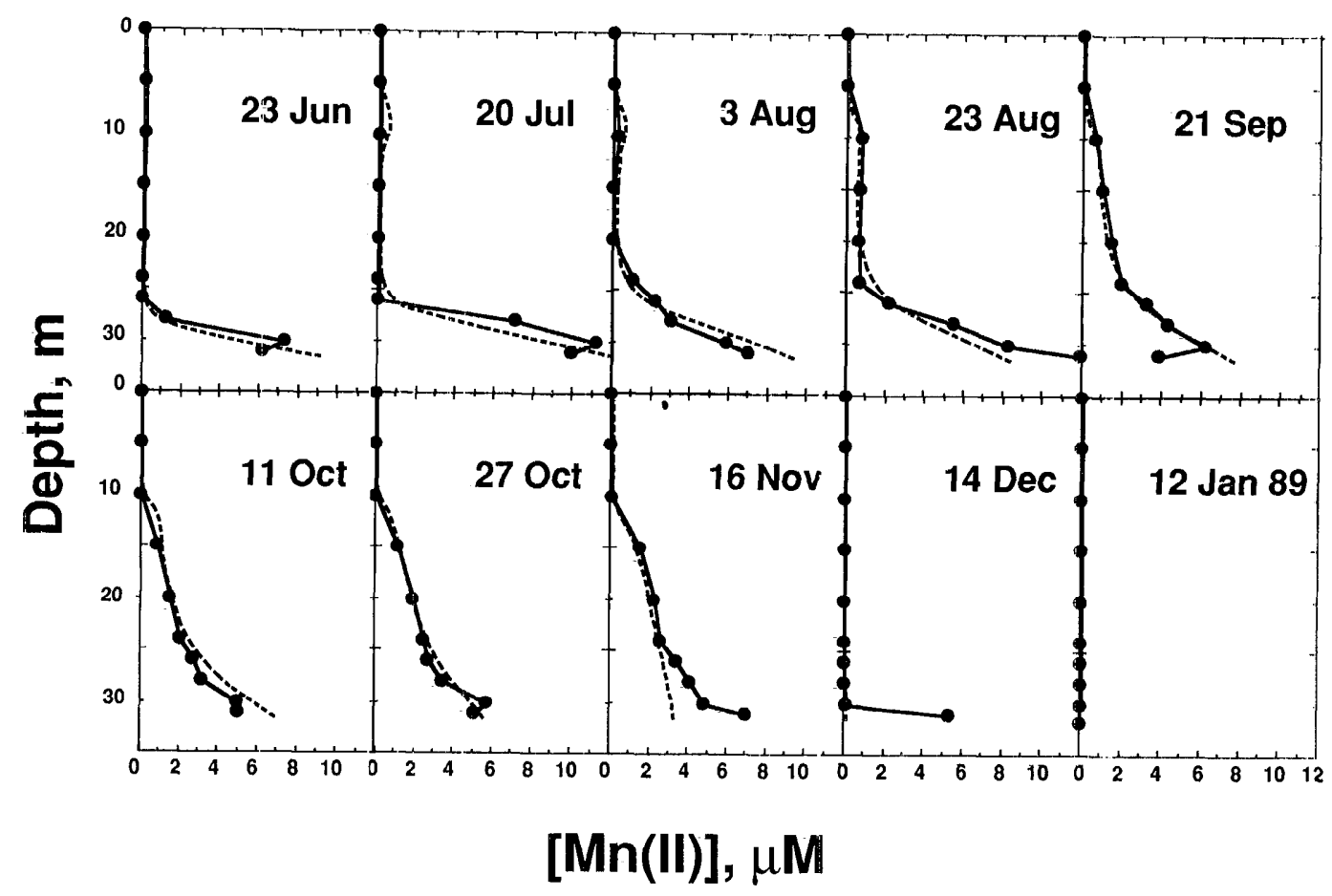

Fig. 3. Comparison of simulated and field $\mathrm{Mn}(\mathrm{II})$ depth profiles in Greifensec in 1988. Points represent measured values; dashed lines delineate model calculations.

that time because less $\mathrm{Mn}(\mathrm{II})$ is oxidized. In mid-November the thermocline begins to deepen and by mid-December has reached $30 \mathrm{~m}$. Oxygen is transported to the bottom waters and, consequently, values of $[\mathrm{Mn}]_{\mathrm{p}}$ are higher throughout the water. By January a large proportion of the $\mathbf{M n}_{\mathrm{p}}$ has sedimented.

Predicted $M n(I I)$ profiles (1988) - The most important features of the mcasured $\mathrm{Mn}$ (II) profiles have been simulated by the model (Fig. 3). They include rapid Mn(II) flux from bottom sediments at the beginning of the stagnation period, followed by diffusion of $\mathrm{Mn}$ (II) from the lateral sediments later in the season and decline in [Mn(II)] in bottom waters with time. At the end of the season the simulated Mn(II) concentrations in bottom waters substantially underestimate the field data. This result suggests increased flux by a process not included in the calculations.

The flux, $F$, of $\mathrm{Mn}$ (II) from the sediments is the most important process for the de- termination of $\mathrm{Mn}$ (II) profiles. The $\mathrm{Mn}$ (II) profiles could be reproduced only if $\mathrm{Mn}$ (II) flux from the sediments was allowed to vary temporally (Fig. 4). At the beginning of oxygen depletion in bottom waters (June 1988), the flux of $\mathrm{Mn}$ (II) from the sediments was $1 \mathrm{mmol} \mathrm{m}^{-2} \mathrm{~d}^{-1}$, but after $30 \mathrm{~d}$ it decreased almost exponentially. The model is most sensitive to magnitude of the Mn(II) flux. A doubling or halving of $F$ is directly reflected in the total Mn(II) content of the lake during the entire period of simulation (Table 6).

The values of flux determined from calculations (Fig. 4) are within the range of values cited in the literature (Table 1). Hunt (1983) measured Mn(II) fluxed from sediments in Narrangansett Bay and not only substantiated previous findings that the flux was correlated with temperature, but also that it was dependent on primary productivity. In Greifensee the temperature in bottom waters varied from $5.2^{\circ} \mathrm{C}$ at the beginning of June to $\sim 6.2^{\circ} \mathrm{C}$ in December. The 


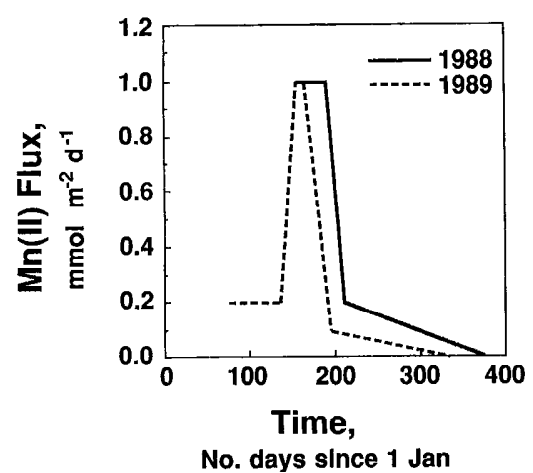

Fig. 4. Values of Mn(II) flux used in model calculations of the 1988 and 1989 data scts. More important than the absolute values is the seasonal trend of $\mathrm{Mn}(\mathrm{II})$ flux.

Mn(II) flux was, thus, unrelated to temperature, but more probably a function of organic detritus originating in surface waters and to the amount of reducible Mn oxides in the surface layers of the sediments.

The oxygen threshold concentration $\left[\mathrm{O}_{2}\right]_{\mathrm{f}}$ used in these calculations was $5 \times 10^{-5} \mathrm{M}$. $\mathrm{Mn}$ (II) actually begins to diffuse from sediments when oxygen concentrations are in the range of $3-15 \times 10^{-5} \mathrm{M}(8$ June 1988 , Fig. 2). Other studies confirm this observation (Sundby et al. 1986; Tipping et al. 1985). The flux chamber studies of Sundby et al. (1986) show a strong inverse correlation between oxygen concentrations and

Table 6. Sensitivity of the model for the Mn cycle to variations in model parameters (model A). The parameters were set to half or double (low/high) their standard value (Table 5). Only one parameter was varicd at a time. The table lists the time-averaged fraction of the simulation results for $\mathrm{Mn}$ (II) calculated with the modified parameter set to standard parameter set. The value taken for comparison was the total $\mathrm{Mn}$ (II) content in the lake below 5-m depth.

\begin{tabular}{|c|c|c|}
\hline Parameter & Low & High \\
\hline Sediment flux of $\mathrm{Mn}(\mathrm{II}), F$ & 0.50 & 2.00 \\
\hline $\begin{array}{l}\text { Threshold oxygen concentration } \\
\text { sediment flux, }\left[\mathrm{O}_{2}\right]_{\mathrm{f}} \\
\text { Oxidation rate of } \mathrm{Mn}(\mathrm{II}) \text { to } \mathrm{Mn}\end{array}$ & 0.85 & 1.32 \\
\hline oxide, $k_{\text {ox }}$ & 12.39 & 0.74 \\
\hline $\begin{array}{l}88 \text { and } 12 \text { Jan } 89 \\
\text { Threshold oxygen concentration }\end{array}$ & 1.12 & 0.90 \\
\hline $\mathrm{Mn}(\mathrm{II})$ oxidation, $\left[\mathrm{O}_{2}\right]_{\mathrm{ox}}$ & 0.72 & 1.58 \\
\hline
\end{tabular}

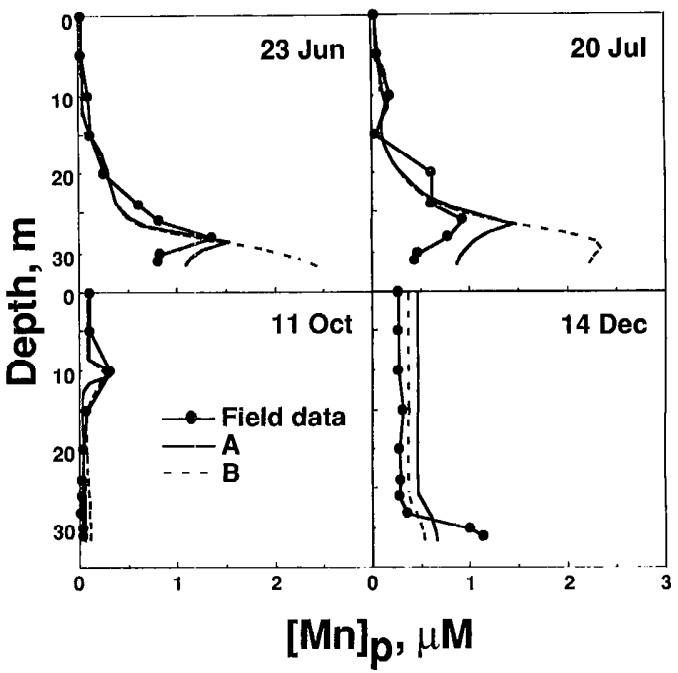

Fig. 5. Comparison of simulated and field $\mathrm{Mn}_{\mathrm{p}}$ depth profiles in Greifensec in 1988 . Points represent measurcd values; lines delineate model calculations. Model A-oxidation described as pseudo-first-order reaction with respect to $\mathrm{Mn}$ (II) above the oxygen threshold value. Model B-second-order reaction with oxygen included in a Michaelis-Menten relationship.

Mn(II) fluxes at the beginning of anoxia. In relating this finding to the model calculations in Greifensec, we would achieve a more accurate representation of the flux by determining the relationship between $\mathrm{Mn}$ (II) flux to the oxygen concentration and the maximal amount of $\mathrm{Mn}$ oxides available for reduction in the sediment. The amount of field data is, however, insufficient for such a detailed analysis.

Particulate Mn profiles (1988) - The $\mathrm{Mn}_{\mathrm{p}}$ profiles are generated by a combination of the $\mathrm{Mn}$ (II) flux, $\mathrm{Mn}$ (II) oxidation, and $\mathrm{Mn}_{\mathrm{p}}$ settling processes. Thus they are more difficult to reproduce in calculations. The dynamics of these processes are reflected by quite rapid temporal changes. Nevertheless the simulated particulate profiles are in general agreement with the measured profiles (Fig. 5).

Residence times of $\mathrm{Mn}$ (II) at the $\mathrm{O}_{2}$ Mn(II) boundary would be on the order of several years if inorganic heterogeneous oxidation were the only oxidative process, whereas the reported microbial oxidation rate constants (Table 2) reduce the residence times to $1-25 \mathrm{~d}$. The $\mathrm{Mn}_{\mathrm{p}}$ profiles in Grei- 
fensee can be reproduced only with rate constants akin to those in Table 2 , in agreement with Emerson (1980). Calculations showed that the oxidation rate value had to be over a certain minimum, but that above this value $\left(\sim 0.1 \mathrm{~d}^{-1}\right)$ the results were quite insensitive to the chosen rate constant (Table 6). To obtain an optimal oxidation rate, we would have to investigate this process as a function of sampling frequency and at shorter sampling intervals than done in this study. The oxidation rate constant, $k_{\mathrm{ox}}$, chosen was $0.2 \mathrm{~d}^{-1}[\mathrm{Mn}(\mathrm{II})$ residence time $\sim 5$ d].

The oxygen threshold concentration $\left[\mathrm{O}_{2}\right]_{\mathrm{ox}}$ used in model A was a critical parameter, chosen on the basis of the overlap of the $\mathrm{O}_{2}$ and $\mathrm{Mn}$ (II) profiles. The optimal value was $3 \times 10^{-5} \mathrm{M}$. The critical data sets for this choice were 23 June-3 August, since the most pronounced $[\mathrm{Mn}]_{\mathrm{p}}$ peaks were found during this interval. Not much $\mathrm{Mn}_{\mathrm{p}}$ is formed at the thermocline later in the season because the flux of $\mathrm{Mn}$ (II) into the oxygen-containing zone is smaller.

Model B was constructed on the basis of model $\mathrm{A}$. The same value of oxidation constant was used $\left(k_{\mathrm{ox}}=0.2 \mathrm{~d}^{-1}\right)$, and the threshold oxygen concentration was incorporated into a Michaelis-Menten expression for oxygen. In effect, the two models are very similar except that model B allows oxidation of $\mathrm{Mn}(\mathrm{II})$, albeit at reduced rates, below the oxygen threshold value. The results of model A and B differ most strongly in the reproduction of the $[\mathrm{Mn}]_{\mathrm{p}}$ peaks (Fig. $5)$. The peaks can best be reproduced by model A. Model B obvicusly overestimates the oxidation rate of $\mathrm{Mn}(\mathrm{II})$ at low $\left[\mathrm{O}_{2}\right]$ and, because this model most resembles the oxygen dependence of microbial oxidation, explanations must be sought. One of the reasons could be that the oxidizing bacteria are concentrated at the overlap zones of $\mathrm{Mn}(\mathrm{II})$ and $\mathrm{O}_{2}$ with the optimal conditions. Another possible reason could be that $\mathrm{Mn}$ oxide reduction occurs at depth but that the reductants are too short lived to be determined analytically in these suboxic waters.

The coagulation rate $k_{\mathrm{co}}$ of $\mathrm{Mn}_{\mathrm{p}}$ with other particles in the water was determined on the basis of the removal of the $\left[\mathrm{Mn}_{\mathrm{p}}\right]$ peak from 3 to 23 August. Linear interpolation between the data sets gave a coagulation rate $k_{\text {co }}$ of $0.035 \mathrm{~d}^{-1}$ with respect to $\mathrm{Mn}_{\mathrm{p}}$.

Application of the model to the 1989 data set-The model was used to simulate the field data of the following year, 1989. The purpose was to determine applicability of the model to different data sets in the same field system. The $\mathrm{Mn}(\mathrm{II})$ oxidation and $\mathrm{Mn}_{\mathrm{p}}$ coagulation rate constants $k_{\mathrm{ox}}$ and $k_{\text {co }}$ were not altered, but the $\mathrm{Mn}$ (II) flux from the sediments was allowed to vary in order to reproduce the field data.

In this season sampling started before the stagnation period when oxygen levels in the bottom waters were $\sim 2.3 \times 10^{-4} \mathrm{M}$. This timing proved to be critical for the choice of oxygen threshold concentration of the $\mathrm{Mn}$ (II) flux from the sediments. For the first $64 \mathrm{~d}$ of calculation (15 March-18 May) the threshold value $\left[\mathrm{O}_{2}\right]_{\mathrm{f}}$ has been set at $1.5 \times$ $10^{-4} \mathrm{M}$. Above this value, the $[\mathrm{Mn}]_{\mathrm{p}}$ is too high and the predicted $\mathrm{Mn}$ (II) content is still too low. The subsequent profiles (Fig. 6) have been simulated with an oxygen threshold value $\left[\mathrm{O}_{2}\right]_{\mathrm{f}}$ of $5 \times 10^{-5} \mathrm{M}$, as used for the 1988 data set. The Mn(II) profiles simulated subsequent to 18 May are no longer affected by this problem, and the results are in good agreement with the field data until November.

The concurrence of the seasonal trend of Mn(II) flux rates in 1988 and 1989 (Fig. 4) is surprising. The results indicate that initially there is an large flux of Mn(II) from the sediments that decreases rapidly. This pattern could be due to the aforementioned correlation between biological activity and flux rate or to the limited availability of reducible $\mathrm{Mn}$. The relatively low flux at the beginning of the 1989 data set can be explained by the inverse relationship between values of $\left[\mathrm{O}_{2}\right]$ and $\mathrm{Mn}$ (II) fluxes that have been observed in flux-chamber investigations (Sundby et al. 1986).

The underestimation of the Mn(II) flux in bottom waters at the end of the season in 1988 is also seen in November 1989. At these times, small concentrations of Fe(II) and S(-II) are present in the water. These reductants may cause higher $\mathrm{Mn}$ (II) flux by reacting with $\mathrm{Mn}$ oxides which were not 


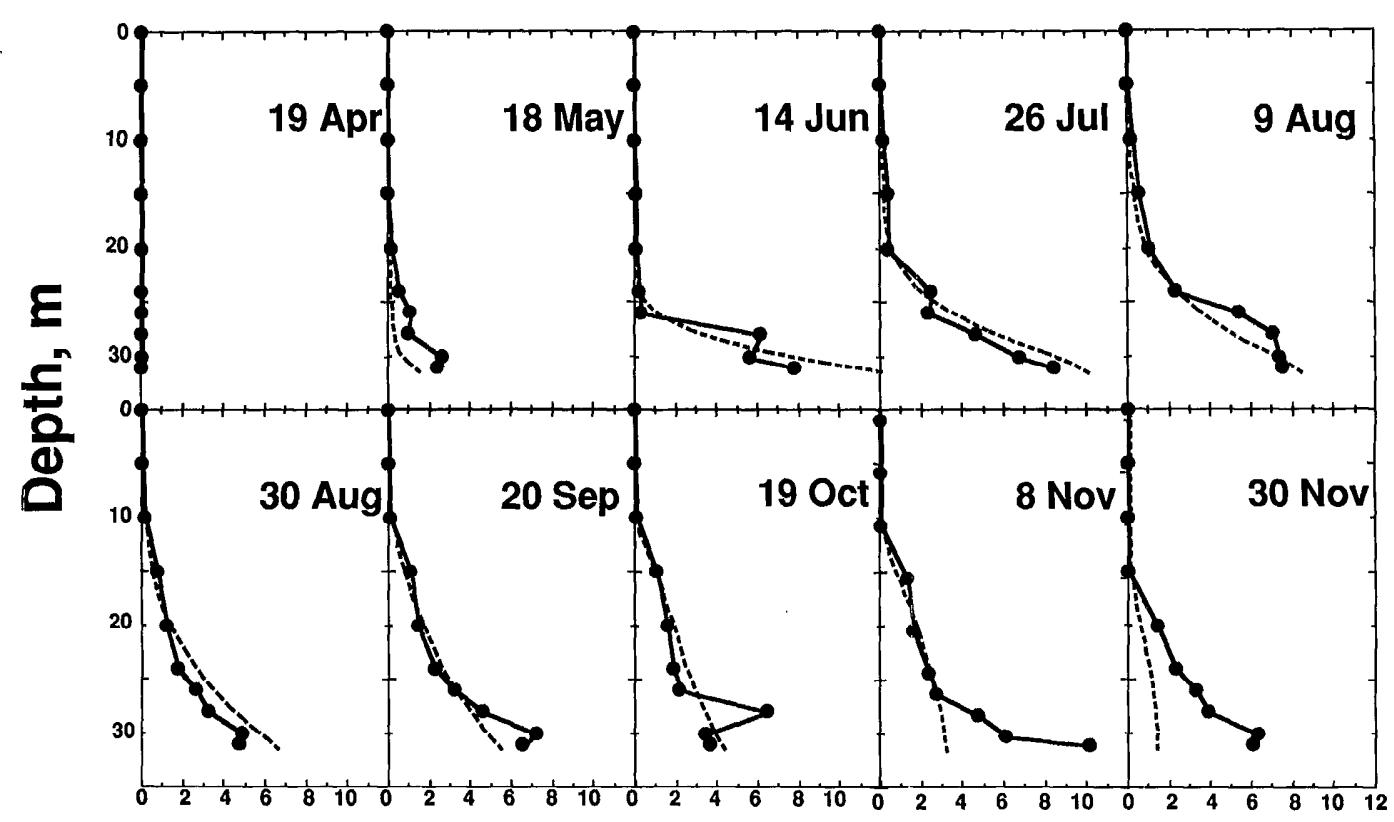

[Mn(II)], $\mu \mathrm{M}$

Fig. 6. Comparison of simulated and field $\mathrm{Mn}$ (II) depth profiles in Greifensee in 1989. Points represent measured values; dashed line delineates model calculations.

available to Mn-reducing biota in the sediment or by reducing $\mathrm{Mn}_{\mathrm{p}}$ in the water.

\section{Conclusions}

Our calculations have shown that it is possible to represent the Mn cycle in Greifensee with a time-dependent model. The values of constants determined in this work should be treated with caution, keeping the assumptions of the model in mind. More important is the demonstration that such models can provide a greater understanding and highlight the gaps in knowledge of the Mn cycle in lacustrine systems. The most important controls of the Mn cycle in the lake seem to be the flux of $\mathrm{Mn}$ (II) from the sediments, the oxidation of Mn(II), and subsequent settling of $\mathrm{Mn}$ oxide. Oxygen plays a critical role because it determines when and where the first two reactions occur. The model is simple, but appropriate for the amount of available field data. A more detailed model and a more realistic representation of the processes would re- quire a correspondingly detailed data set with regard to both time and space.

The model was most useful in elucidating the $\mathrm{Mn}$ (II) flux into the water column. It appears that the flux is greatest at the onset of anoxia and thereafter decreases rapidly. This phenomenon could be related to primary productivity or to the availability of biologically reducible $\mathrm{Mn}$ oxides. There is also an indication that the flux increases as the result of reduction by S(-II) or Fe(II) as these species diffuse through the top layers of the sediment into the water. Model calculations show that $\mathrm{Mn}(\mathrm{II})$ oxidation rates are similar to those determined for microbial oxidation; overall the agreement between predicted and field $\mathbf{M n}_{\mathrm{p}}$ profiles is acceptable. The $\mathrm{Mn}_{\mathrm{p}}$ peaks cannot be reproduced, however, by the model appropriate for microbial oxidation kinetics.

A number of open questions have been highlighted. They include the relationship between $\left[\mathrm{O}_{2}\right]$ and the $\mathrm{Mn}$ (II) flux and the $\mathrm{Mn}$ (II) oxidation reaction and the dynamics 
of $\mathrm{Mn}$ oxide production, coagulation, and settling that result in the formation of $\mathrm{Mn}_{\mathrm{p}}$ peaks. We hope that our work will stimulate answers to these questions and that the utility of these calculations has been demonstrated.

\section{References}

Balikungeri, A., D. Robin, and W. Haerdi. 1985. Manganese in natural waters. 2. Evidence for microbiological oxidation of $\mathrm{Mn}$ (II). Toxicol. Environ. Chem. 9: 309-325.

Brandl, H. 1987. Mikrobielle Prozesse unter oxidationsmittellimitierten Bedingungen an der Sediment-Wasser-Übergangszone in Seen. Ph.D. thesis, Univ. Zürich. 201 p.

Burdige, D. J., AND J. M. Gieskes. 1983. A pore water/solid phase diagenetic model for manganesc in marine sediments. Am. J. Sci. 283: 29-47.

Chapnick, S. D., W. S. Moore, and K. H. Nealson. 1982. Microbially mediated manganese oxidation in a freshwater lake. Limnol. Oceanogr. 27: 1004-1014.

Davies, S. H. R., AND J. J. MCrgan. 1989. Manganese(II) oxidation kinetics on metal oxide surfaces. J. Colloid Interface Sci. 129: 63-77.

Davison, W. 1985. Conceptual models for transport at a redox boundary, p. 31-54. In W. Stumm [ed.], Chemical processes in lakes. Wiley-Interscience.

—_ AND C. WOOF. 1984. A study of the cycling of manganese and other elements in a seasonally anoxic lake, Rostherne Mere, U.K. Water Res. 18: 727-734.

DE VITRE, R. 1986. Multimethod characterization of the forms of iron, manganese and sulfur in a eutrophic lake (Bret, Vaud). Ph.D. thesis 2224, Univ. Geneva. 251 p.

EhrLich, H. L. 1987. Manganese oxide reduction as a form of anaerobic respiration. Geomicrobiol. J. 5: $423-431$.

EMERSON, S. 1980. Redox species in a reducing fjord: The oxidation rate of manganese II, p. 681-687. In Fjord oceanography. NATO Conf. Ser. 4. V. 4. Plenum.

- R. E. Cranston, ANd P. S. Liss. 1979. Redox species in a reducing fjord: Equilibrium and kinetic considerations. Deep-Sea Res. 26: 859-878.

Ghiorse, W. C. 1985. Microbial reduction of manganese and iron, p. 305-331. In A. J. B. Zehnder [ed.], Biology of anaerobic microorganisms. Wiley-Interscience.

Hunt, C. D. 1983. Variability in the benthic Mn flux in coastal marine ecosystems resulting from temperature and primary production. Limnol. Oceanogr. 28: 913-923.

IMBODEN, D. M., B. S. F. EID, T. JOLLER, M. SCHURTER, AND J. Wetzel. 1979. MELIMEX, an experi- mental heavy metal pollution study: Vertical mixing in a large limno-corral. Schweiz. Z. Hydrol. 41: $177-189$.

-, AND T. JOLLER. 1984. Turbulent mixing in the hypolimnion of Baldeggersee (Switzerland) traced by natural radon-222. I imnol. Oceanogr. 29: $831-844$.

--, AND R. P. Schwarzenbach. 1985. Spatial and temporal distribution of chemical substances in lakes: Modeling concepts, p. 1-30. In W. Stumm [ed.], Chemical processes lakes. Wiley-Interscience.

MÜlleR, B., AND L. SIGG. 1990. Interaction of trace metals with natural particle surfaces: Comparison between adsorption experiments and field measurements. Aquat. Sci. 52: 75-92.

Murray, J. W. 1987. Mechanisms in the distribution of trace elements in oceans and lakes, p. 153-183. In Sources and fates of aquatic pollutants. ACS Symp. Ser. 216.

Noye, J. [ED.]. 1984. Computational techniques for differential equations. Math. Stud. 83. North-Holland.

SigG, L., C. A. Johnson, And A. KuHn. 1991. Redox conditions and alkalinity gencration in a scasonally anoxic lake (Lake Greifen). Mar. Chem. 33: in press.

Stone, A. T., and J. J. Morgan. 1987. Reductive dissolution of metal oxides, p. 221-254. In W. Stumm [ed.], Aquatic surface chemistry. Wiley.Interscience.

Stumm, W., And J. J. Morgan. 1981. Aquatic chemistry, 2nd ed. Wiley-Interscience.

Sundby, B., AND OTHERS. 1986. The effect of oxygen on the release and uptake of cobalt, manganese iron and phosphate at the sediment-water interface. Geochim. Cosmochim. Acta 50: 1281-1288.

TEBo, B. M., AND S. EMERSON. 1985. Effect of oxygen tension, $\mathrm{Mn}(\mathrm{II})$ concentration, and temperature on the microbially catalyzed $\mathrm{Mn}$ (II) oxidation rate in a marine fjord. Appl. Environ. Microbiol. 50: 12681273.

Tipping, E., J. G. Jones, ANd C. Woof. 1985. Lacustrine manganese oxides: $\mathrm{Mn}$ oxidation states and relationships to "Mn depositing bacteria." Arch. Hydrobiol. 105: 161-175.

Ulrich, M. 1989. CHEMSEE II, Programm-Anleitung. Users manual.

VoJaK, P. W. L., C. EDWARd, AND M. V. JoNes. 1985. Evidence for microbiological manganese oxidation in the River Tamar estuary, South West England. Estuarine Coastal Shelf Sci. 20: 661-671.

Weilenmann, U., C. R. O'Melia, and W. Stumm. 1989. Particle transport in lakes: Models and measurements. Limnol. Oceanogr. 34: 1-18.

Submitted: 26 October 1990 Accepted: 22 January 1991 Revised: 30 July 1991 